Check for updates

Cite this: RSC Adv., 2018, 8, 39091

Received 30th September 2018 Accepted 10th November 2018

DOI: $10.1039 / \mathrm{c} 8 \mathrm{ra0} 8125 \mathrm{e}$

rsc.li/rsc-advances

\section{Cyperane and eudesmane-type sesquiterpenoids from Chinese liverwort and their anti-diabetic nephropathy potential $\dagger$}

\author{
Jiaozhen Zhang, ${ }^{a}$ Yongjie Wang, (DD ${ }^{\mathrm{b}}$ Rongxiu Zhu, ${ }^{\mathrm{c}}$ Yi Li, ${ }^{a}$ Yuelan Li, ${ }^{a}$ Yanan Qiao, ${ }^{a}$ \\ Jinchuan Zhou ${ }^{d}$ and Hongxiang Lou iD *a
}

\begin{abstract}
Six new sesquiterpenoids, including cyperane ( 1 and 2) and eudesmane (3-6) types, and one known eudesmane derivative (7), were isolated from the Chinese liverwort Chiloscyphus polyanthus var. rivularis (Schrad.) Nees. The structures of 1-7 were determined based on a combination of their spectroscopic data (NMR, HRESIMS and IR), single-crystal X-ray diffraction, and electronic circular dichroism (ECD) calculations. Preliminary anti-diabetic nephropathy activity testing showed that the cyperane-type sesquiterpenoids could inhibit cell proliferation and extracellular matrix accumulation in high glucose cultured mesangial cells in a dose-dependent manner.
\end{abstract}

\section{Introduction}

Diabetic nephropathy (DN) is one of the most serious complications of diabetes mellitus. ${ }^{\mathbf{1} 2}$ It is characterized by mesangial cell (MC) proliferation and overproduction of extracellular matrix (ECM) such as fibronectin (FN) and collagen IV (Col IV), and can lead to renal failure and end-stage renal disease. ${ }^{3-5}$ Currently, clinically available drugs for DN are scarce. ${ }^{6}$ Thus, it is a promising approach to find new drug candidates from natural products.

Reportedly, a number of sesquiterpenoids have shown their potential in the treatment of DN. ${ }^{7-10}$ Liverworts are rich source of bioactive sesquiterpenoids. ${ }^{\mathbf{1 1 - 1 4}}$ Previous chemical investigations on the Chinese liverwort Chiloscyphus polyanthus var. rivularis (Schrad.) Nees, collected in the Changbaishan mountain at Jilin Province of China, has led to the isolation of several enteudesmane-type sesquiterpenoids. ${ }^{15}$ In order to hunt for sesquiterpenoids with anti-DN activity, our further research on the same species led to the discovery of six new sesquiterpenoids including the cyperane (1 and 2) and ent-eudesmane (3-6) types, together with one known ent-eudesmane-type sesquiterpenoid

${ }^{a}$ Department of Natural Products Chemistry, Key Lab of Chemical Biology of the Ministry of Education, Shandong University, Jinan 250012, People's Republic of China. E-mail: louhongxiang@sdu.edu.cn; Fax: +86-531-8838-2019; Tel: +86-5318838-2012

${ }^{b}$ Department of Pharmacy, The Second Hospital of Shandong University, Jinan, Shandong 250033, People's Republic of China

'School of Chemistry and Chemical Engineering, Shandong University, Jinan 250010, People's Republic of China

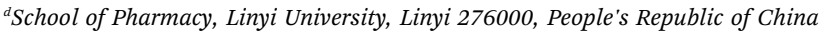

$\dagger$ Electronic supplementary information (ESI) available. CCDC 1471130 and 1863078. For ESI and crystallographic data in CIF or other electronic format see DOI: $10.1039 / \mathrm{c} 8 \mathrm{ra} 08125 \mathrm{e}$
(7). The anti-DN activities of the isolated compounds were evaluated by inhibiting the cell proliferation and the accumulation of ECM. Herein, we report the isolation, structural elucidation, and preliminary anti-DN activity of these compounds.

\section{Results and discussion}

\subsection{Isolation and identification of undescribed compounds}

The 95\% EtOH extract of air-dried C. polyanthus var. rivularis was fractionated by chromatography over MCI gel, silica gel and Sephadex LH-20 and was then further purified by semipreparative HPLC to afford six previously undescribed sesquiterpenoids and one known analogue (Fig. 1). Their structures were determined based on their spectroscopic data, singlecrystal X-ray diffraction, and ECD calculations.

Compound 1 was obtained as colorless needles. The molecular formula was established as $\mathrm{C}_{15} \mathrm{H}_{26} \mathrm{O}_{3}$ based on the pseudo molecular ion $[\mathrm{M}+\mathrm{Na}]^{+}$peak at $\mathrm{m} / \mathrm{z} 277.1777$ (calcd 277.1774) in the HRESIMS and ${ }^{13} \mathrm{C}$ NMR data, requiring three indices of hydrogen deficiency. The IR spectrum revealed an absorption band for one carbonyl group $\left(1680 \mathrm{~cm}^{-1}\right)$. The ${ }^{1} \mathrm{H}$ NMR data (Table 1) of 1 displayed signals for two tertiary methyls at $\delta_{\mathrm{H}} 0.95(\mathrm{~s})$ and $2.14(\mathrm{~s})$, two secondary methyls at $\delta_{\mathrm{H}}$ $0.98(\mathrm{~d}, J=6.7 \mathrm{~Hz})$ and $0.99(\mathrm{~d}, J=6.7 \mathrm{~Hz})$, and one oxygenated methine at $\delta_{\mathrm{H}} 4.36(\mathrm{dd}, J=8.1,6.0 \mathrm{~Hz})$. The ${ }^{13} \mathrm{C}$ NMR (Table 1) and HMQC data showed 15 carbons including one carbonyl group $\left(\delta_{\mathrm{C}} 212.8\right.$ ), three quaternary carbons (with one of these oxygenated at $\delta_{\mathrm{C}} 71.6$ ), two methines (one oxygenated at $\delta_{\mathrm{C}}$ 77.4), five methylenes, and four methyls. The above NMR data showed that 1 was a derivative of 4-oxo-cyperan-3 $\alpha, 7 \alpha, 11$-triol bearing a cyperane skeleton, ${ }^{\mathbf{1 6}}$ in which the oxygenated quaternary carbon at C-11 was replaced by a methine group $\left(\delta_{\mathrm{H}}\right.$ 


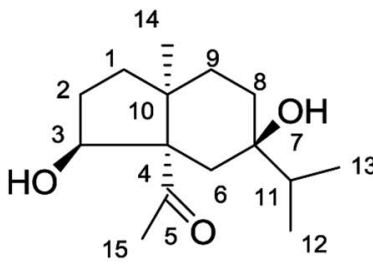

1

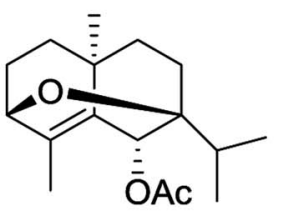

5<smiles>CC(=O)C12CC(O)(C(C)C)CC[C@@]1(C)CC[C@@H]2O</smiles>

2

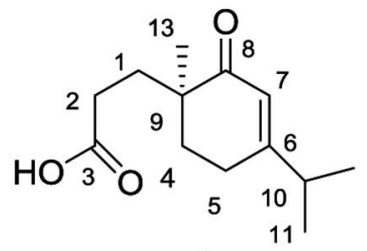

6<smiles>[R]C1=C2C([13CH3])[C@@H](O)CC[C@]2(C)CC[C@]1(O)C(C)C</smiles>

$3 \mathrm{R}=\mathrm{OH}$

$4 \mathrm{R}=\mathrm{H}$<smiles>CC1=C2[C@@H](O)C(O)(C(C)C)CC[C@]2(C)CCC1=O</smiles>

7

Fig. 1 Structures of compounds $1-7$

Table $1{ }^{1} \mathrm{H}(400 \mathrm{MHz})$ and ${ }^{13} \mathrm{C}(100 \mathrm{MHz})$ NMR data of compounds 1 and 2 in $\mathrm{CDCl}_{3}$ ( $\delta$ in ppm)

\begin{tabular}{|c|c|c|c|c|}
\hline \multirow[b]{2}{*}{ Pos. } & \multicolumn{2}{|l|}{1} & \multicolumn{2}{|l|}{2} \\
\hline & $\delta_{\mathrm{C}}$ & $\delta_{\mathrm{H}}$ & $\delta_{\mathrm{C}}$ & $\delta_{\mathrm{H}}$ \\
\hline $1 \alpha$ & $37.7 \mathrm{t}$ & $1.76 \mathrm{~m}$ & $37.7 \mathrm{t}$ & $1.87 \mathrm{~m}$ \\
\hline $1 \beta$ & & $1.49 \mathrm{~m}$ & & $1.42 \operatorname{ddd}(12.6,9.5,2.9)$ \\
\hline $2 \alpha$ & $34.5 \mathrm{t}$ & $2.34 \mathrm{~m}$ & $31.2 \mathrm{t}$ & $2.30 \mathrm{~m}$ \\
\hline $2 \beta$ & & $1.81 \mathrm{~m}$ & & $1.73 \mathrm{~m}$ \\
\hline 3 & $77.4 \mathrm{~d}$ & $4.36 \mathrm{dd}(8.1,6.0)$ & $78.2 \mathrm{~d}$ & $5.22 \mathrm{dd}(10.0,7.0)$ \\
\hline 4 & $212.8 \mathrm{~s}$ & & $213.8 \mathrm{~s}$ & \\
\hline 5 & $65.2 \mathrm{~s}$ & & $64.4 \mathrm{~s}$ & \\
\hline $6 \alpha$ & $32.6 \mathrm{t}$ & $2.01 \mathrm{~d}(15.0)$ & $33.3 \mathrm{t}$ & $2.01 \mathrm{~d}(14.5)$ \\
\hline $6 \beta$ & & $1.94 \mathrm{~d}(15.0)$ & & $1.87 \mathrm{~d}(14.5)$ \\
\hline 7 & $71.6 \mathrm{~s}$ & & $73.1 \mathrm{~s}$ & \\
\hline 8 & $30.2 \mathrm{t}$ & $1.50 \mathrm{~m}$ & $30.1 \mathrm{t}$ & $1.55 \mathrm{~m}$ \\
\hline $9 \alpha$ & $33.0 \mathrm{t}$ & $1.20 \mathrm{br} \mathrm{d}(10.5)$ & $33.0 \mathrm{t}$ & 1.16 br d (13.9) \\
\hline $9 \beta$ & & $1.95 \mathrm{~m}$ & & $1.87 \mathrm{~m}$ \\
\hline 10 & $43.4 \mathrm{~s}$ & & $42.7 \mathrm{~s}$ & \\
\hline 11 & $39.2 \mathrm{~d}$ & 1.69 sept (6.7) & $40.1 \mathrm{~d}$ & 1.63 sept (6.8) \\
\hline 12 & $17.2 \mathrm{q}$ & $0.99 \mathrm{~d}(6.7)$ & $16.8 \mathrm{q}$ & $0.99 \mathrm{~d}(6.8)$ \\
\hline 13 & $17.1 \mathrm{q}$ & $0.98 \mathrm{~d}(6.7)$ & $16.7 \mathrm{q}$ & $0.96 \mathrm{~d}(6.8)$ \\
\hline 14 & $22.9 \mathrm{q}$ & $0.95 \mathrm{~s}$ & $22.3 \mathrm{q}$ & $0.94 \mathrm{~s}$ \\
\hline 15 & $29.8 \mathrm{q}$ & $2.14 \mathrm{~s}$ & $31.2 \mathrm{q}$ & $2.15 \mathrm{~s}$ \\
\hline
\end{tabular}

1.69 sept $\left.J=6.7, \delta_{\mathrm{C}} 39.2\right)$ in 1 . The ${ }^{1} \mathrm{H}^{-1} \mathrm{H}$ COSY correlations (Fig. 2) of 1 established three segments: $\mathrm{CH}_{2}(1)-\mathrm{CH}_{2}(2)-\mathrm{CH}(3)$, $\mathrm{CH}_{2}(8)-\mathrm{CH}_{2}(9)$, and $\mathrm{CH}_{3}(12)-\mathrm{CH}(11)-\mathrm{CH}_{3}(13)$. The keto carbonyl at C-4 was confirmed using HMBC correlations (Fig. 2)
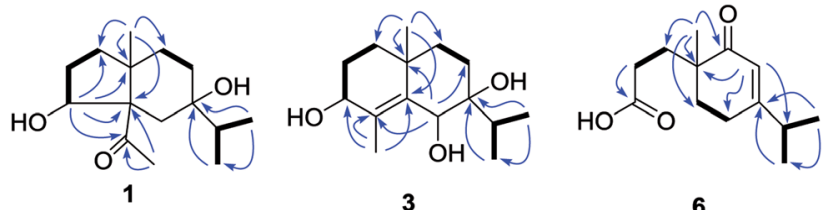

Fig. 2 Selected $\mathrm{HMBC}(\mathrm{H} \rightarrow \mathrm{C})$ and ${ }^{1} \mathrm{H}-{ }^{1} \mathrm{H} \operatorname{COSY}(\mathrm{H}-\mathrm{H})$ correlations of 1,3 and 6 from $\mathrm{H}_{3}-15\left(\delta_{\mathrm{H}} 2.14\right)$ to $\mathrm{C}-4$ and $\mathrm{C}-5\left(\delta_{\mathrm{C}} 65.2\right)$. The hydroxyl groups at $\mathrm{C}-3$ and $\mathrm{C}-7$ were verified by the $\mathrm{HMBC}$ correlations from $\mathrm{H}-3\left(\delta_{\mathrm{H}} 4.36\right)$ to $\mathrm{C}-1\left(\delta_{\mathrm{C}} 37.7\right), \mathrm{C}-4, \mathrm{C}-5$ and $\mathrm{C}-10\left(\delta_{\mathrm{C}} 43.4\right)$, and from $\mathrm{H}_{3}-12 / 13\left(\delta_{\mathrm{H}} 0.98\right.$ and 0.99$)$ to $\mathrm{C}-7\left(\delta_{\mathrm{C}} 71.6\right)$, respectively. Thus, the gross structure of $\mathbf{1}$ was determined as shown. The NOESY correlation (Fig. 3) of $\mathrm{H}_{3}-14 / \mathrm{H}_{3}-15, \mathrm{H}-1 \beta / \mathrm{H}-9 \alpha / \mathrm{H}-9 \beta$, and $\mathrm{H}-2 \beta / \mathrm{H}-9 \beta$ indicated the two rings were cis-fused and the NOESY correlations between $\mathrm{H}-3$ and $\mathrm{H}_{3}-15$ suggested the hydroxyl group of C-3 was $\beta$-oriented. Single-crystal X-ray diffraction analysis with $\mathrm{Cu} \mathrm{K} \alpha$ radiation (Fig. 4) was operated to establish the unambiguous assignment of its relative and absolute configurations. Therefore, compound $\mathbf{1}$ was identified as $(3 S, 5 S, 7 R, 10 S)$-3,7-dihydroxy-cyperan-4-one.

Compound 2 was found to share the same planar structure with compound 1 based on the same molecular formula $\left[\mathrm{C}_{15} \mathrm{H}_{26} \mathrm{O}_{3}, \mathrm{~m} / \mathrm{z} 277.1766[\mathrm{M}+\mathrm{Na}]^{+}\right.$(calcd 277.1774) in the

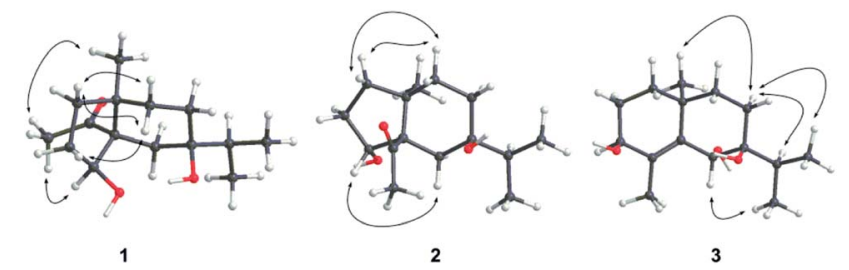

Fig. 3 Selected NOESY correlations $(H \leftrightarrow H)$ of 1, 2 and 3 .
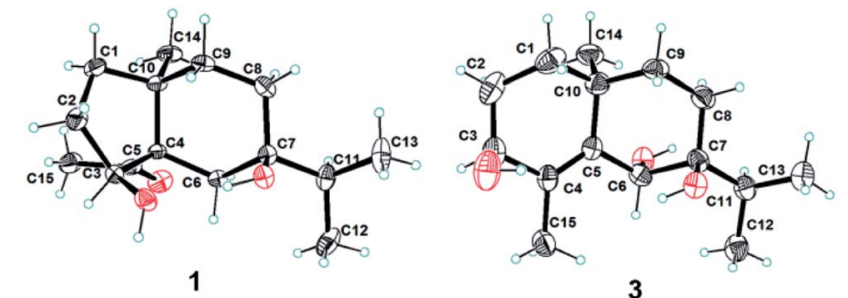

Fig. 4 X-ray crystallographic structures of 1 and 3. 


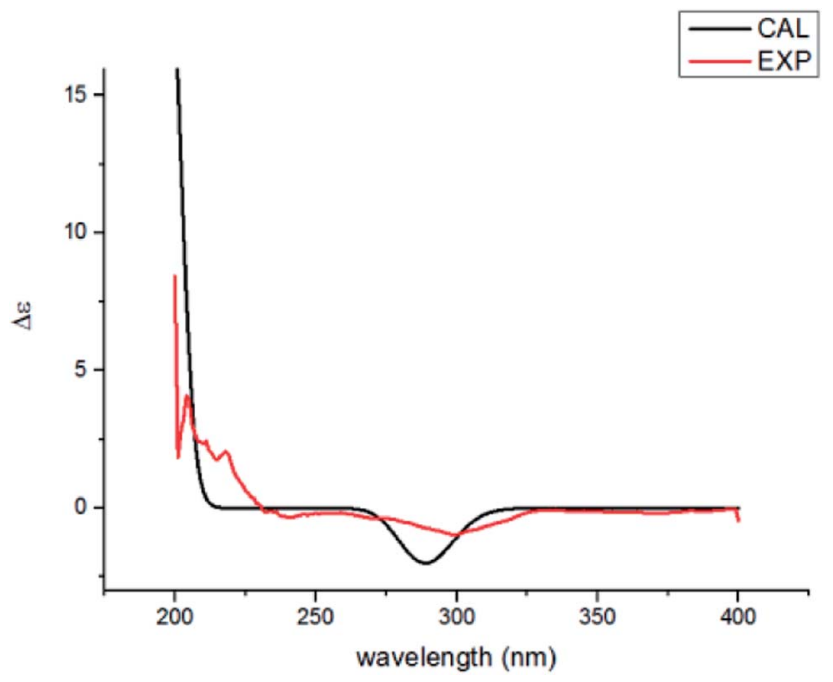

Fig. 5 Experimental ECD (red) and calculated ECD (black) of 2.

HRESIMS of 2] and similar NMR data (Table 1). In comparison of their ${ }^{1} \mathrm{H}$ NMR data, the most observable change is the downfield shift of $0.86 \mathrm{ppm}$ for $\mathrm{H}-3\left(\delta_{\mathrm{H}} 5.22, \mathrm{dd}, J=10.0,7.0 \mathrm{~Hz}\right)$ in 2 which implied its configuration at C-3 is different with compound 1. In the NOE spectrum of 2, correlations of $\mathrm{H}-3 / \mathrm{H}-$ $6 \beta$ confirmed the $\mathrm{OH}-3$ was $\alpha$-oriented and correlations of $\mathrm{H}-9 \alpha /$ $\mathrm{H}-1 \alpha / \mathrm{H}-1 \beta$ suggested the presence of trans-fused rings (Fig. 3). Above conclusion was verified by the negative Cotton effect at $299 \mathrm{~nm}$ in its ECD spectrum, which was contrary to the positive Cotton effect at $302 \mathrm{~nm}$ in the ECD spectrum of 1 and suggested the inverse configuration of the chiral center adjacent keto carbonyl of $2 .{ }^{17}$ Thus, the structure of 2 was determined as $(3 R, 5 R, 7 R, 10 S)-3,7$-dihydroxy-cyperan-4-one, which was further supported by the agreement exhibiting in experimental and calculated electronic circular dichroism (ECD) spectra of 2 (Fig. 5).

Compound 3 was obtained as colorless needles with a molecular formula of $\mathrm{C}_{15} \mathrm{H}_{26} \mathrm{O}_{3}$, based on its HRESIMS at $\mathrm{m} / \mathrm{z}$ $277.1775[\mathrm{M}+\mathrm{Na}]^{+}$(calcd 277.1774), which indicated three degrees of unsaturation. The IR spectrum showed absorptions at $3391 \mathrm{~cm}^{-1}$ suggesting the presence of hydroxy groups. The ${ }^{1} \mathrm{H}$ NMR data (Table 2) displayed the signals of two tertiary methyls at $\delta_{\mathrm{H}} 1.20(\mathrm{~s})$ and $1.90(\mathrm{~s})$, a isopropyl group including two secondary methyls at $\delta_{\mathrm{H}} 0.96(\mathrm{~d}, J=7.0 \mathrm{~Hz})$ and $1.02(\mathrm{~d}, J=7.0$ $\mathrm{Hz}$ ) and a methine at $\delta_{\mathrm{H}} 2.03$ (sept, $J=7.0 \mathrm{~Hz}$ ), two oxygenated methines at $\delta_{\mathrm{H}} 3.90(\mathrm{~d}, J=3.2 \mathrm{~Hz})$ and $4.53(\mathrm{~s})$. The ${ }^{13} \mathrm{C}$ NMR (Table 2) and HMQC data showed 15 carbons as two vinylic carbons $\left(\delta_{\mathrm{C}} 134.6\right.$ and 139.0), two quaternary carbons (with one of these oxygenated at $\delta_{\mathrm{C}} 75.4$ ), three methines (two oxygenated at $\delta_{\mathrm{C}} 70.1$ and 70.0), four methylenes, and four methyls $\left(\delta_{\mathrm{C}} 16.1\right.$, 16.2, 26.0 and 17.4). Three spin systems $\mathrm{CH}_{2}(1)-\mathrm{CH}_{2}(2)-\mathrm{CH}(3)$, $\mathrm{CH}_{2}(8)-\mathrm{CH}_{2}(9)$, and $\mathrm{CH}_{3}(12)-\mathrm{CH}(11)-\mathrm{CH}_{3}(13)$ from the ${ }^{1} \mathrm{H}^{-}{ }^{1} \mathrm{H}$ COSY spectrum (Fig. 2), as well as the HMBC correlations from $\mathrm{H}_{3}-15\left(\delta_{\mathrm{H}} 1.90\right)$ to $\mathrm{C}-3\left(\delta_{\mathrm{C}} 70.1\right), \mathrm{C}-4\left(\delta_{\mathrm{C}} 134.6\right)$, and C-5 $\left(\delta_{\mathrm{C}} 139.0\right)$; from $\mathrm{H}_{3}-12\left(\delta_{\mathrm{H}} 1.02\right)$ and $\mathrm{H}_{3}-13\left(\delta_{\mathrm{H}} 0.96\right)$ to $\mathrm{C}-11\left(\delta_{\mathrm{C}} 33.0\right)$, and C$7\left(\delta_{\mathrm{C}} 75.4\right)$; from $\mathrm{H}_{3}-14\left(\delta_{\mathrm{H}} 1.20\right)$ to $\mathrm{C}-1\left(\delta_{\mathrm{C}} 35.3\right), \mathrm{C}-5$, C-9 $\left(\delta_{\mathrm{C}}\right.$ $36.4)$, and C-10 $\left(\delta_{\mathrm{C}} 33.7\right)$; from $\mathrm{H}-6\left(\delta_{\mathrm{H}} 4.53\right)$ to C-4, C-5, C-7, C-8 $\left(\delta_{\mathrm{C}} 26.4\right)$ and $\mathrm{C}-10$ furnished the planar structure of compound 3 , which was the same as that of eudesm-4-ene-3 $\alpha, 6 \alpha, 7 \alpha$-triol. ${ }^{18}$ The semblable 1D NMR data recorded in DMSO- $d_{6}$ with the sole difference of the chemical shift of $\mathrm{H}-6\left(\delta_{\mathrm{H}} 4.24\right.$ for compound 3 , and $\delta_{\mathrm{H}} 4.24$ for the reported compound), and the NOE correlations of $\mathrm{H}_{3}-13 / \mathrm{H}-11 / \mathrm{H}-8 \alpha$, and $\mathrm{H}-8 \alpha / \mathrm{H}_{3}-14$ of compound 3 (Fig. 3), indicated that these two compounds shared the same relative configuration, except that at C-6. Single-crystal X-ray

Table $2{ }^{1} \mathrm{H}(400 \mathrm{MHz})$ and ${ }^{13} \mathrm{C}(100 \mathrm{MHz}) \mathrm{NMR}$ data of compounds 3 and 4 ( $\delta$ in ppm)

\begin{tabular}{|c|c|c|c|c|c|c|}
\hline \multirow[b]{2}{*}{ Pos. } & \multicolumn{2}{|l|}{$3^{a}$} & \multicolumn{2}{|l|}{$\mathbf{3}^{b}$} & \multicolumn{2}{|l|}{$\mathbf{4}^{a}$} \\
\hline & $\delta_{\mathrm{C}}$ & $\delta_{\mathrm{H}}$ & $\delta_{\mathrm{C}}$ & $\delta_{\mathrm{H}}$ & $\delta_{\mathrm{C}}$ & $\delta_{\mathrm{H}}$ \\
\hline $1 \alpha$ & $35.3 \mathrm{t}$ & $1.33 \mathrm{dt}(12.8,3.0)$ & $35.1 \mathrm{t}$ & $1.09 \mathrm{~m}$ & $34.0 \mathrm{t}$ & $1.42 \mathrm{~m}$ \\
\hline $1 \beta$ & & $1.59 \mathrm{~m}$ & & $1.57 \mathrm{~m}$ & & $1.67 \mathrm{~m}$ \\
\hline $2 \alpha$ & $27.7 \mathrm{t}$ & $1.92 \mathrm{~m}$ & $27.9 \mathrm{t}$ & $1.74 \mathrm{~m}$ & $27.9 \mathrm{t}$ & $1.75 \mathrm{~m}$ \\
\hline $2 \beta$ & & $1.74 \mathrm{~m}$ & & $1.54 \mathrm{~m}$ & & \\
\hline 3 & $70.1 \mathrm{~d}$ & $3.90 \mathrm{~d}(3.2)$ & $68.3 \mathrm{~d}$ & $3.64 \mathrm{t}(4.4)$ & $69.8 \mathrm{~d}$ & $3.87 \mathrm{br} \mathrm{s}$ \\
\hline 4 & $134.6 \mathrm{~s}$ & & $131.2 \mathrm{~s}$ & & $130.0 \mathrm{~s}$ & \\
\hline 5 & $139.0 \mathrm{~s}$ & & $138.2 \mathrm{~s}$ & & $137.1 \mathrm{~s}$ & \\
\hline $6 \alpha$ & $70.0 \mathrm{~d}$ & $4.53 \mathrm{~s}$ & $68.2 \mathrm{~d}$ & $4.24 \mathrm{~d}(3.2)$ & $33.9 \mathrm{t}$ & 1.99 br d (14.4) \\
\hline $6 \beta$ & & & & & & $2.45 \mathrm{dd}(14.4,2.4)$ \\
\hline 7 & $75.4 \mathrm{~s}$ & & $73.8 \mathrm{~s}$ & & $75.4 \mathrm{~s}$ & \\
\hline $8 \alpha$ & $26.4 \mathrm{t}$ & $1.81 \mathrm{~m}$ & $26.1 \mathrm{t}$ & $1.65 \mathrm{~m}$ & $29.3 \mathrm{t}$ & $1.44 \mathrm{~m}$ \\
\hline $8 \beta$ & & $1.61 \mathrm{~m}$ & & $1.41 \mathrm{~m}$ & & $1.63 \mathrm{~m}$ \\
\hline 9 & $36.4 \mathrm{t}$ & $1.50 \mathrm{~m}$ & $36.3 \mathrm{t}$ & $1.20 \mathrm{~m}$ & $37.6 \mathrm{t}$ & $1.53 \mathrm{~m}$ \\
\hline & & & & $1.50 \mathrm{~m}$ & & \\
\hline 10 & $33.7 \mathrm{~s}$ & & $33.1 \mathrm{~s}$ & & $34.9 \mathrm{~s}$ & \\
\hline 11 & $33.0 \mathrm{~d}$ & 2.03 sept (7.0) & $32.6 \mathrm{~d}$ & 1.88 sept $(6.8)$ & $38.3 \mathrm{~d}$ & 1.63 sept $(6.8)$ \\
\hline 12 & $16.1 \mathrm{q}$ & $1.02 \mathrm{~d}(7.0)$ & $16.4 \mathrm{q}$ & $0.89 \mathrm{~d}(6.8)$ & $17.2 \mathrm{q}$ & $0.98 \mathrm{~d}(6.8)$ \\
\hline 13 & $16.2 \mathrm{q}$ & $0.96 \mathrm{~d}(7.0)$ & $16.2 \mathrm{q}$ & $0.84 \mathrm{~d}(6.8)$ & $17.4 \mathrm{q}$ & $0.98 \mathrm{~d}(6.8)$ \\
\hline 14 & $26.0 \mathrm{q}$ & $1.20 \mathrm{~s}$ & $25.6 \mathrm{q}$ & $1.11 \mathrm{~s}$ & $22.6 \mathrm{q}$ & $0.99 \mathrm{~s}$ \\
\hline 15 & $17.4 \mathrm{q}$ & $1.90 \mathrm{~s}$ & $17.0 \mathrm{q}$ & $1.72 \mathrm{~s}$ & $17.3 \mathrm{q}$ & $1.77 \mathrm{~s}$ \\
\hline
\end{tabular}

${ }^{a}$ Recorded in $\mathrm{CDCl}_{3} \cdot{ }^{b}$ Recorded in DMSO- $d_{6}$. 
diffraction analysis with $\mathrm{Cu} \mathrm{K} \alpha$ radiation (Fig. 4) was employed to confirm the aforementioned conclusion, and determine the absolute configuration of this compound. The structure of 3 was therefore elucidated as $(3 S, 6 R, 7 S, 10 S)$-3,6,7-trihydroxyeudesma- $4 E$-ene.

Compound 4 was assigned a molecular formula of $\mathrm{C}_{15} \mathrm{H}_{26} \mathrm{O}_{2}$, with three degrees of unsaturation, based on its HRESIMS $(\mathrm{m} / \mathrm{z}$ 261.1831 [M $+\mathrm{Na}]^{+}$, calcd 261.1825) and NMR spectra (Table 2). Analysis of the ${ }^{1} \mathrm{H}$ and ${ }^{13} \mathrm{C}$ NMR data revealed that the planar structure of 4 is same with that of 3,7-dihydroxy-eudesma-4-ene, ${ }^{19}$ which was previously synthesized and reported with the uncertain configuration of C-3. In addition, the reported NMR data of $\mathrm{H}-3\left(\delta_{\mathrm{H}} 4.13\right)$ was slightly different with that of compound $4\left(\delta_{\mathrm{H}}\right.$ 3.87 ) and the hydroxyl group at $\mathrm{C}-3$ of compound 4 was $\beta$ oriented, as supported by NOESY correlations of $\mathrm{H}-3 / \mathrm{H}-1 \alpha\left(\delta_{\mathrm{H}}\right.$ 1.42) and $\mathrm{H}-1 \alpha / \mathrm{H}_{3}-14\left(\delta_{\mathrm{H}} 0.99\right)$. Thus, the structure of 4 was determined as $(3 S, 7 R, 10 S)$-3,7-dihydroxy-eudesma-4Z-ene.

Compound 5 was deduced to have the molecular formula, $\mathrm{C}_{17} \mathrm{H}_{26} \mathrm{O}_{3}$, from its HRESIMS $\left(m / z\right.$ 279.1949 $[\mathrm{M}+\mathrm{H}]^{+}$, calcd 279.1955) and ${ }^{13} \mathrm{C}$ NMR data, indicating five indices of hydrogen deficiency. Comparison of the 1D NMR data (Table 3) with those of compound 3 showed the absence of a hydroxyl group and the presence of a acetyl group $\left(\delta_{\mathrm{H}} 2.13 ; \delta_{\mathrm{C}} 21.4\right.$ and 170.2) at C-6. The HMBC correlations from $\mathrm{H}-3\left(\delta_{\mathrm{H}} 3.80\right)$ to $\mathrm{C}-7 \quad\left(\delta_{\mathrm{C}} 78.3\right)$ of compound 5 and the one more degree of unsaturation compared with compound 3 suggested the presence of an oxygen bridge connecting C-3 and C-7. The NOESY correlations between $\mathrm{H}-1 \alpha\left(\delta_{\mathrm{H}}\right.$ 1.44) and $\mathrm{H}_{3}-14\left(\delta_{\mathrm{H}} 1.12\right), \mathrm{H}_{3}-14$ and $\mathrm{H}-9 \alpha\left(\delta_{\mathrm{H}} 1.52\right)$ as well as $\mathrm{H}-1 \beta$ $\left(\delta_{\mathrm{H}} 1.62\right)$ and $\mathrm{H}-9 \beta\left(\delta_{\mathrm{H}} 1.48\right)$ supported the relative configuration of $\mathbf{5}$, and the structure of $\mathbf{5}$ was assigned as $(3 S, 6 R, 7 S, 10 S)-3,7-$ epoxy-6acetoxy-eudesma- $4 E$-ene from a biosynthetic standpoint.

Table $3{ }^{1} \mathrm{H}(600 \mathrm{MHz})$ and ${ }^{13} \mathrm{C}(150 \mathrm{MHz}) \mathrm{NMR}$ data of compounds 5 and 6 in $\mathrm{CDCl}_{3}$ ( $\delta$ in ppm)

\begin{tabular}{|c|c|c|c|c|}
\hline \multirow[b]{2}{*}{ Pos. } & \multicolumn{2}{|l|}{5} & \multicolumn{2}{|l|}{6} \\
\hline & $\delta_{\mathrm{C}}$ & $\delta_{\mathrm{H}}$ & $\delta_{\mathrm{C}}$ & $\delta_{\mathrm{H}}$ \\
\hline $1 \alpha$ & $34.7 \mathrm{t}$ & $1.44 \mathrm{dt}(13.2,4.2)$ & $31.4 \mathrm{t}$ & $1.88 \mathrm{~m}$ \\
\hline $1 \beta$ & & $1.62 \mathrm{~m}$ & & \\
\hline $2 \alpha$ & $27.6 \mathrm{t}$ & $1.72 \mathrm{~m}$ & $28.2 \mathrm{t}$ & $2.35 \mathrm{~m}$ \\
\hline \multicolumn{5}{|l|}{$2 \beta$} \\
\hline 3 & $70.7 \mathrm{~d}$ & $3.80 \mathrm{br} \mathrm{s}$ & $177.7 \mathrm{~s}$ & \\
\hline $4 a$ & $130.6 \mathrm{~s}$ & & $34.0 \mathrm{t}$ & $1.90 \mathrm{~m}$ \\
\hline $4 \mathrm{~b}$ & & & & $1.75 \mathrm{~m}$ \\
\hline 5 & $135.4 \mathrm{~s}$ & & $24.7 \mathrm{t}$ & $2.35 \mathrm{~m}$ \\
\hline 6 & $75.6 \mathrm{~d}$ & $5.61 \mathrm{~s}$ & $170.0 \mathrm{~s}$ & \\
\hline 7 & $78.3 \mathrm{~s}$ & & $122.5 \mathrm{~d}$ & $5.79 \mathrm{~s}$ \\
\hline $8 \alpha$ & $25.2 \mathrm{t}$ & $1.72 \mathrm{~m}$ & $203.7 \mathrm{~s}$ & \\
\hline $8 \beta$ & & $1.55 \mathrm{~m}$ & & \\
\hline $9 \alpha$ & $37.6 \mathrm{t}$ & $1.52 \mathrm{~m}$ & $43.2 \mathrm{~s}$ & \\
\hline $9 \beta$ & & $1.48 \mathrm{~m}$ & & \\
\hline 10 & $37.8 \mathrm{~s}$ & & $35.5 \mathrm{~d}$ & 2.39 sept (6.9) \\
\hline 11 & $33.4 \mathrm{~d}$ & 2.05 sept (7.2) & $20.9 \mathrm{q}$ & $1.11 \mathrm{~d}(6.9)$ \\
\hline 12 & $16.6 \mathrm{q}$ & $0.84 \mathrm{~d}(7.2)$ & $20.9 \mathrm{q}$ & $1.01 \mathrm{~d}(6.9)$ \\
\hline 13 & $17.5 \mathrm{q}$ & $0.98 \mathrm{~d}(7.2)$ & $22.0 \mathrm{q}$ & $1.09 \mathrm{~s}$ \\
\hline 14 & $22.8 \mathrm{q}$ & $1.12 \mathrm{~s}$ & & \\
\hline 15 & $17.7 \mathrm{q}$ & $1.88 \mathrm{~s}$ & & \\
\hline \multirow[t]{2}{*}{ OAc } & $170.2 \mathrm{~s}$ & & & \\
\hline & $21.4 \mathrm{q}$ & $2.13 \mathrm{~s}$ & & \\
\hline
\end{tabular}

Compound 6 displayed a molecular formula of $\mathrm{C}_{13} \mathrm{H}_{20} \mathrm{O}_{3}$, as determined by its NMR (Table 3 ) and HRESIMS $(\mathrm{m} / \mathrm{z} 225.1481$ $[\mathrm{M}+\mathrm{H}]^{+}$, calcd 225.1485) data and was assigned as a norsesquiterpenoid. It was found to represent one trisubstituted double bond $\left(\delta_{\mathrm{C}} 170.0\right.$ and $\left.\delta_{\mathrm{H}} 5.79 \mathrm{~s}, \delta_{\mathrm{C}} 122.5\right)$, one carbonyl group $\left(\delta_{\mathrm{C}} 203.7\right)$, one carboxyl group $\left(\delta_{\mathrm{C}} 177.7\right)$, one isopropyl group $\left[\delta_{\mathrm{H}} 2.39 \mathrm{sept}(6.9), \delta_{\mathrm{C}} 35.5 ; \delta_{\mathrm{H}} 1.01 \mathrm{~d}(6.9), \delta_{\mathrm{C}} 20.9 \& \delta_{\mathrm{H}}\right.$ $\left.1.11 \mathrm{~d}(6.9), \delta_{\mathrm{C}} 20.9\right]$ and one tertiary methyl $\left(\delta_{\mathrm{H}} 1.09 \mathrm{~s}, \delta_{\mathrm{C}} 22.0\right)$. The structure of this 4,5-scco-eudesmane-type norsesquiterpenoid was confirmed by the HMBC correlations (Fig. 2) from $\mathrm{H}_{3}-13$ to $\mathrm{C}-1\left(\delta_{\mathrm{C}} 31.4\right)$, C-4 $\left(\delta_{\mathrm{C}} 34.0\right)$, C-8 $\left(\delta_{\mathrm{C}} 203.7\right)$ and C-9 $\left(\delta_{\mathrm{C}} 43.2 \mathrm{~s}\right)$ as well as from $\mathrm{H}_{2}-2\left(\delta_{\mathrm{H}} 2.35 \mathrm{~m}\right)$ to C-3 $\left(\delta_{\mathrm{C}} 177.7\right)$. As C9 is the sole chiral center in the structure, absolute configuration of $\mathbf{6}$ was confirmed by comparing their specific rotation with the data in literature, ${ }^{20}$ and its structure was defined as (9S)-4,5-seco-4-nor-3-carboxy-9-oxo-eudesma-6E-ene.

One known ent-eudesmane-type sesquiterpenoid, namely, $(6 R, 7 S, 10 R)-6,7-d i h y d r o x y-3-o x o-e u d e s m a-4 E$-ene (7), was isolated and identified by comparing their observed and reported ESIMS and NMR data. ${ }^{21}$

\subsection{Preliminary anti-DN activity testing of isolated compounds}

The anti-DN activities of compounds 1-7 were evaluated. Among them, the cyperane-type sesquiterpenoids $\mathbf{1}$ and $\mathbf{2}$ can inhibit cell proliferation and ECM (FN and Col IV) accumulation in rat glomerular MCs cultured under high glucose condition. As shown in Fig. 6A, compared with normal glucose (NG) and isoosmotic mannitol (Man) control groups, high glucose (HG) dramatically promoted MC proliferation and treatment with compound 1 or $\mathbf{2}$ could inhibit HG-induced MC proliferation in a concentration-dependent manner. The accumulation of glomerular ECM proteins is involved the development of DN. Thus, we measured the effect of isolated sesquiterpenoids on ECM proteins expression in MCs induced by HG. The results of ELISA and western blot analysis demonstrated that, compared with control groups, the protein expression levels of $\mathrm{FN}$ and $\mathrm{Col}$ IV were markedly increased in HG group. Strikingly, compounds $1(40 \mu \mathrm{M})$ and $2(80 \mu \mathrm{M})$ obviously reversed HGinduced protein expression levels of $\mathrm{FN}$ and $\mathrm{Col}$ IV in MCs (Fig. 6B-E). In addition, cytotoxic test against MCs was carried out using the MTT method, and the results showed that all the compounds exhibited no toxic effects at $80 \mu \mathrm{M}$.

\section{Experimental section}

\subsection{General experimental procedures}

NMR spectra were recorded on a Bruker Avance DRX-600 spectrometer $\left({ }^{1} \mathrm{H}: 600 \mathrm{MHz},{ }^{13} \mathrm{C}: 150 \mathrm{MHz}\right)$ and Bruker Avance AVIII400 spectrometer $\left({ }^{1} \mathrm{H}: 400 \mathrm{MHz},{ }^{13} \mathrm{C}: 100 \mathrm{MHz}\right)$, and TMS was used as internal standard. HRESIMS were obtained using an LTQOrbitrap XL. Melting points were measured using an X-6 micromelting point apparatus (uncorrected). Optical rotations were acquired on a MCP 200 modular circular polarimeter. UV data were recorded using a Shimadzu UV-2550 spectrophotometer. ECD spectra were performed on a Chirascan spectropolarimeter. IR 

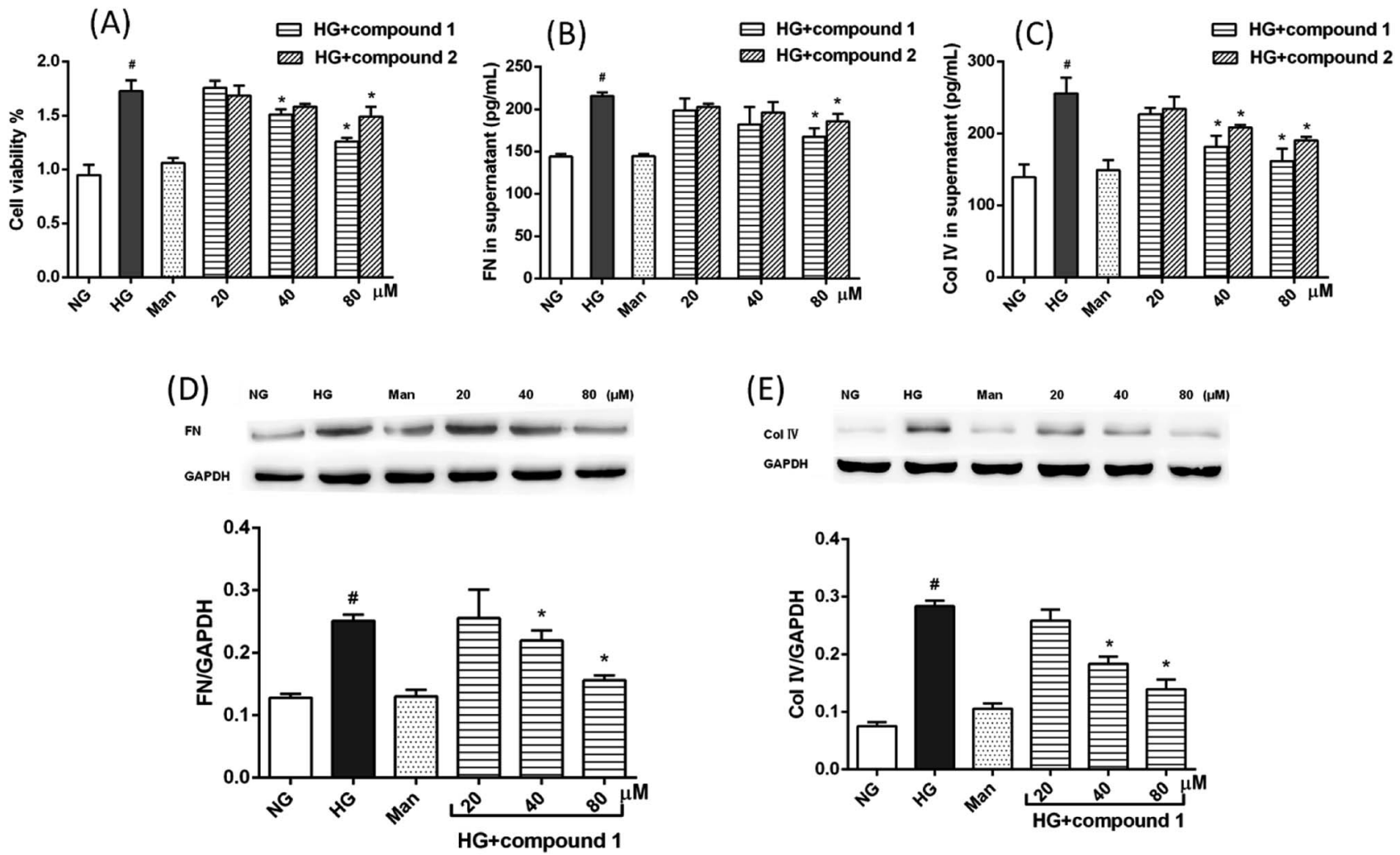

Fig. 6 Inhibitory effects of compounds 1 and 2 on high glucose-cultured rat glomerular MCs. (A) Compounds 1 and 2 inhibit HG-induced MC proliferation. (B-E) Compounds 1 and 2 inhibit HG-induced ECM (FN and Col IV) expression in MCs. (B and C) The productions of FN and Col IV in MCs cultured under different conditions were tested by ELISA. (D and E) Western blot analysis were performed to detect the protein expression levels of FN and Col IV, MCs cultured under different conditions. NG: cells treated with $5.5 \mathrm{mM}$ glucose; Man: cells treated with $5.5 \mathrm{mM}$ glucose plus $24.5 \mathrm{Mm}$; HG: cells treated with high glucose $30 \mathrm{mM}$. Data are presented as the means $\pm \mathrm{SEM}, n=3$. ${ }^{\#} P<0.05 \mathrm{vs}$. NG; *P<0.05 vs. HG.

spectra were measured on a Nicolet iN 10 Micro FTIR spectrometer. HPLC was carried out on an Agilent 1200 series instrument with Eclipse XDB- $\mathrm{C}_{18} 5 \mu \mathrm{m}$ columns $(4.6 \times 250 \mathrm{~mm}$ and $9.4 \times 250$ $\mathrm{mm})$. MCI gel (CHP20P, 75-150 $\mu \mathrm{m}$, Mitsubishi Chemical Industries Ltd.), silica gel (200-300 mesh; Yantai Huanghai Chemical Co. Ltd.), Sephadex LH-20 (25-100 $\mu \mathrm{m}$; Pharmacia), and reversedphase $\mathrm{C}_{18}$ silica gel (150-200 mesh, Merck) were used for column chromatography.

\subsection{Plant material}

Whole plants of C. polyanthus were collected from wet soil along the River of Changbaishan Mountain, Jilin Province, People's Republic of China, in July 2014, and identified by Dr Jinchuan Zhou (College of Pharmaceutical Sciences, Linyi University). A voucher specimen (no. 20140725-09) has been deposited at the Department of Natural Products Chemistry, School of Pharmaceutical Sciences, Shandong University, People's Republic of China.

\subsection{Extraction and isolation}

The air-dried and milled plant material from C. polyanthus var. rivularis $(780 \mathrm{~g})$ was extracted with $95 \% \mathrm{EtOH}(4 \times 1.5 \mathrm{~L}$, each for one week) at room temperature and filtered. The filtrate was evaporated under reduced pressure at $40{ }^{\circ} \mathrm{C}$ to afford the crude extract $(36.0 \mathrm{~g})$, which was suspended in $\mathrm{H}_{2} \mathrm{O}(250 \mathrm{~mL})$ and partitioned successively with $\mathrm{Et}_{2} \mathrm{O}(3 \times 250 \mathrm{~mL})$ and $n$ - $\mathrm{BuOH}(3$ $\times 250 \mathrm{~mL}$ ). The $\mathrm{Et}_{2} \mathrm{O}$ fraction $(8.0 \mathrm{~g})$ was separated by MCI gel column chromatography $\left(\mathrm{MeOH}-\mathrm{H}_{2} \mathrm{O}, 3: 7\right.$ to $\left.9: 1\right)$ and gave fractions 1-4. Fraction 2 (1.6 g) was chromatographed using a silica gel column [petroleum ether $\left(60-90^{\circ} \mathrm{C}\right)$-acetone, $200: 1$ to $0: 1$ ] to give subfractions $2 \mathrm{~A}-2 \mathrm{~F}$. Fraction $2 \mathrm{E}(292.6 \mathrm{mg})$ was applied to a Sephadex LH-20 column (MeOH) and a RP-18 silica gel column $\left(\mathrm{MeOH} / \mathrm{H}_{2} \mathrm{O}, 5: 5\right.$ to $\left.10: 0\right)$ to afford subfractions E1-E7. Subfraction E5 $(94.5 \mathrm{mg})$ was purified by HPLC to afford $1(19.4 \mathrm{mg})$, and $3(3.5 \mathrm{mg})$ was afforded from subfraction E1 (17.71 mg) by recrystallization. Fraction $2 \mathrm{~F}(345.1 \mathrm{mg})$ was subjected to a Sephadex LH-20 column (MeOH) and an RP-18 silica gel column $\left(\mathrm{MeOH}-\mathrm{H}_{2} \mathrm{O}, 4: 6\right.$ to $\left.9: 1\right)$ to afford subfractions F1-F8. Subfraction F1 (7.59 mg) was purified using HPLC to yield $4(2.7 \mathrm{mg})$ and $6(0.8 \mathrm{mg})$. Subfraction F2 (20.3 $\mathrm{mg}$ ) was purified using HPLC to yield $7(6.2 \mathrm{mg})$. Subfraction F6 (20.9 $\mathrm{mg}$ ) was purified using HPLC to yield 2 (5.1 $\mathrm{mg})$, and 5 (1.1 $\mathrm{mg})$.

3.3.1. Compound 1. Colorless crystals $(\mathrm{MeOH}) ; \mathrm{mp} 188-$ $189^{\circ} \mathrm{C} ;[\alpha]_{\mathrm{D}}^{25}-32.4(c 0.05 \mathrm{MeOH}) ; \mathrm{UV}(\mathrm{MeOH}) \lambda_{\max }(\log \varepsilon) 200$ (3.38) nm; ECD (MeOH) $302\left(\Delta \varepsilon\right.$ 0.54) nm; IR $\nu_{\max } 3086,2960$, 2877, 2741, 1680, $1010 \mathrm{~cm}^{-1} ;{ }^{1} \mathrm{H}$ and ${ }^{13} \mathrm{C}$ NMR data, see Table 1; HRESIMS $\mathrm{m} / \mathrm{z} 277.1777[\mathrm{M}+\mathrm{Na}]^{+}$(calcd for $\mathrm{C}_{15} \mathrm{H}_{26} \mathrm{O}_{3} \mathrm{Na}$, 277.1774).

3.3.2. Compound 2. Colorless oil $(\mathrm{MeOH}) ;[\alpha]_{\mathrm{D}}^{25}-25.2(c$ $0.04 \mathrm{MeOH}) ; \mathrm{UV}(\mathrm{MeOH}) \lambda_{\max }(\log \varepsilon) 200(3.38) \mathrm{nm}$; ECD 
$(\mathrm{MeOH}) 299(\Delta \varepsilon-0.06) \mathrm{nm}$; IR $\nu_{\max } 3385,2956,2932,2874$, $1685,1081 \mathrm{~cm}^{-1} ;{ }^{1} \mathrm{H}$ and ${ }^{13} \mathrm{C}$ NMR data, see Table 1; HRESIMS $m / z 277.1766[\mathrm{M}+\mathrm{Na}]^{+}$(calcd for $\mathrm{C}_{15} \mathrm{H}_{26} \mathrm{O}_{3} \mathrm{Na}, 277.1774$ ).

3.3.3. Compound 3. Colorless crystals ( $\mathrm{MeOH})$; mp 193 $194{ }^{\circ} \mathrm{C} ;[\alpha]_{\mathrm{D}}^{25}-56.0(c 0.18 \mathrm{MeOH}) ; \mathrm{UV}(\mathrm{MeOH}) \lambda_{\max }(\log \varepsilon) 242$ (3.01) nm; ECD (MeOH) $216(\Delta \varepsilon+0.07) \mathrm{nm}, 255(\Delta \varepsilon+0.06) \mathrm{nm}$; IR $\nu_{\max } 3391,2931,2875,1698,1649,982 \mathrm{~cm}^{-1} ;{ }^{1} \mathrm{H}$ and ${ }^{13} \mathrm{C}$ NMR data, see Table 2; HRESIMS $m / z$ 277.1775 $[\mathrm{M}+\mathrm{Na}]^{+}$(calcd for $\left.\mathrm{C}_{15} \mathrm{H}_{26} \mathrm{O}_{3} \mathrm{Na}, 277.1774\right)$.

3.3.4. Compound 4. White powder; $[\alpha]_{\mathrm{D}}^{25}-12.8$ (c 0.08 $\mathrm{MeOH}) ; \mathrm{UV}(\mathrm{MeOH}) \lambda_{\max }(\log \varepsilon) 240$ (3.00); 300 (2.67) nm; ECD $(\mathrm{MeOH}) 209(\Delta \varepsilon-3.38) \mathrm{nm}$; IR $\nu_{\max }$ 2962, 2918, 2850, 1710, 1662, 1462, $1218 \mathrm{~cm}^{-1} ;{ }^{1} \mathrm{H}$ and ${ }^{13} \mathrm{C}$ NMR data, see Table 2; HRESIMS $m / z$ 261.1831 $[\mathrm{M}+\mathrm{Na}]^{+}$(calcd for $\mathrm{C}_{15} \mathrm{H}_{26} \mathrm{O}_{2} \mathrm{Na}$, 261.1825).

3.3.5. Compound 5. White powder; $[\alpha]_{\mathrm{D}}^{25}-81.2(c \quad 0.05$ $\mathrm{MeOH}) ; \mathrm{UV}(\mathrm{MeOH}) \lambda_{\max }(\log \varepsilon) 299$ (2.72) nm; ECD (MeOH) 252 $(\Delta \varepsilon-0.23) \mathrm{nm}, 342(\Delta \varepsilon-0.16) \mathrm{nm}$; IR $\nu_{\max } 3393,2958,2953$, 2874, 1738, $1240 \mathrm{~cm}^{-1} ;{ }^{1} \mathrm{H}$ and ${ }^{13} \mathrm{C}$ NMR data, see Table 3; HRESIMS $m / z 279.1949[\mathrm{M}+\mathrm{H}]^{+}$(calcd for $\mathrm{C}_{17} \mathrm{H}_{27} \mathrm{O}_{3}, 279.1955$ ).

3.3.6. Compound 6. Colorless oil $(\mathrm{MeOH}) ;[\alpha]_{\mathrm{D}}^{25}-4.4(c 0.08$ $\mathrm{MeOH}) ; \mathrm{UV}(\mathrm{MeOH}) \lambda_{\max }(\log \varepsilon) 237$ (3.51) nm; ECD (MeOH) 262 $\left(\begin{array}{ll}\Delta \varepsilon & 0.26\end{array}\right) \mathrm{nm}$; IR $\nu_{\max } 2962,2918,2850,1710,1662,1462$, $1218 \mathrm{~cm}^{-1}$; ${ }^{1} \mathrm{H}$ and ${ }^{13} \mathrm{C}$ NMR data, see Table 3 ; HRESIMS $\mathrm{m} / \mathrm{z}$ 225.1481 $[\mathrm{M}+\mathrm{H}]^{+}$(calcd for $\mathrm{C}_{13} \mathrm{H}_{21} \mathrm{O}_{3}, 255.1485$ ).

\subsection{Crystallographic analysis of compounds 1 and 3}

Diffraction intensities for 1 and 3 were collected at $291.15 \mathrm{~K}$ on a Bruker Apex2 CCD diffractometer using $\mathrm{Cu} \mathrm{K} \alpha$ radiation, using Olex2. ${ }^{22}$ The structure was solved with the ShelXS structure solution program using direct methods and refined with the ShelXL refinement package using least squares minimization. ${ }^{23}$

Compound $1\left(\mathrm{C}_{15} \mathrm{H}_{26} \mathrm{O}_{3}, M=254.36 \mathrm{~g} \mathrm{~mol}^{-1}\right)$ : monoclinic, space group $P 1, a=6.9631(10) \AA, b=10.2646(14) \AA, c=$ 15.2511(15) А, $V=730.66(18) \AA^{3}, Z=2, D_{\text {calcd }}=1.156 \mathrm{~g} \mathrm{~cm}^{-3}, \mu$ $(\mathrm{Cu} \mathrm{K} \alpha)=0.623 \mathrm{~mm}^{-1}, F(000)=280, R$ (reflections) $=$ $0.0382(4571), \quad w R_{2}$ (reflections) $=0.0955(5123)$. The flack parameter was $-0.13(11)$. Details of crystallographic data for 1 have been deposited with the Cambridge Crystallographic Data Centre as supplementary publication number CCDC 1471130.

Compound $3\left(\mathrm{C}_{15} \mathrm{H}_{26} \mathrm{O}_{3}, M=254.36 \mathrm{~g} \mathrm{~mol}^{-1}\right)$ : monoclinic,

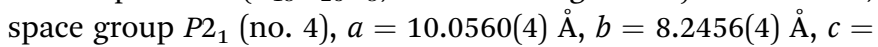
$17.0806(8) \AA, V=1416.28(11) \AA^{3}, Z=2, D_{\text {calcd }}=1.193 \mathrm{~g} \mathrm{~cm}^{-3}, \mu$ $(\mathrm{Cu} \mathrm{K} \alpha)=0.643 \mathrm{~mm}^{-1}, F(000)=560, R$ (reflections) $=$ 0.1302 (3373), $w R_{2}$ (reflections) $=0.3291(4420)$. The flack parameter was $0.0(4)$. Details of crystallographic data for 3 have been deposited with the Cambridge Crystallographic Data Centre as supplementary publication number CCDC 1863078.

\subsection{Anti-DN activity tests}

3.5.1. Cell culture and cell proliferation assay. The rat renal mesangial cell line HBZY-1 (American Type Culture Collection, Manassas, VA) were cultured in Dulbecco's Modified Eagle's Medium (DMEM) containing 10\% fetal bovine serum (FBS), and $1 \%$ penicillin-streptomycin at $37{ }^{\circ} \mathrm{C}$ in a humidified $5 \% \mathrm{CO}_{2}$ atmosphere. At sub-confluence, MCs were cultured for $24 \mathrm{~h}$ in DMEM medium containing $5.5 \mathrm{mM}$ glucose and 0.5\% FBS and then used for experiments. The cells were treated with $5.5 \mathrm{mM}$ glucose (NG), $30 \mathrm{mM}$ glucose (HG), and $24.5 \mathrm{mM}$ mannitol was added along with $5.5 \mathrm{mM}$ glucose as an osmotic control for $24 \mathrm{~h}$. MCs cultured with $30 \mathrm{mM}$ glucose were co-treated with or without compounds 1-7 (20, 40, $80 \mu \mathrm{M})$.

Cell proliferation was measured by 3-(4,5-dimethylthiazol-2yl)-2,5-diphenyl tetrazolium bromide (MTT) assay. In brief, after treatment, $10 \mu \mathrm{L}$ of MTT ( $5 \mathrm{mg} \mathrm{mL}{ }^{-1}$; Sigma Chemical Co., St. Louis, MO, USA) was added to each well and incubation continued at $37{ }^{\circ} \mathrm{C}$ for $4 \mathrm{~h}$. Then, $150 \mathrm{~mL}$ of DMSO (Sigma Chemical Co., St. Louis, MO, USA) was added into each well and the absorbance was measured at $570 \mathrm{~nm}$ using a microplate reader (Bio-Rad, Hercules, CA, USA).

3.5.2. Enzyme linked immunosorbent assay (ELISA). The level of FN or Col IV was measured using a fibronectin or collagen IV Rat ELISA kit (Westdon, Shanghai, China). After exposure to the defined experimental conditions, culture mediums were harvested. Culture mediums were centrifuged and the supernatants were assayed according to the manufacturer's instructions. Absorbance was read at a wavelength of $450 \mathrm{~nm}$ using a microplate reader (Bio-Rad, Hercules, CA, USA).

3.5.3. Western blot analysis. Samples containing $30 \mathrm{mg}$ total protein were loaded on $10 \%$ SDS-polyacrylamide gels and the separated proteins were transferred to polyvinylidene fluoride (PVDF) membranes. The membranes were blocked with 5\% non-fat dry milk in Tris-buffered saline (TBS) for $2 \mathrm{~h}$ and then probed at $4{ }^{\circ} \mathrm{C}$ overnight with primary antibodies (dilution, 1 : 1000), including FN, Col IV and GAPDH, followed by incubation with horseradish peroxidase-conjugated goat anti-rabbit immunoglobulin G (Santa Cruz Biotechnology, Santa Cruz, CA, USA) diluted 1:5000 in the blocking buffer for $2 \mathrm{~h}$. Bound proteins were visualized with the chemiluminescence (ECL) detection system (Amersham, Little Chalfont, UK). Relative protein band density was quantified by image $\mathrm{J}$ software.

3.5.4. Statistics. The data were presented as the mean \pm SEM (standard errors of the mean) of at least three experiments. Unpaired Students's $t$-tests were used for the comparison between two groups. Differences were considered significant if the $P$-value was less than 0.05 .

\section{Conclusions}

In summary, six undescribed sesquiterpenoids, including cyperane and eudesmane types, and one known sesquiterpenoid, were isolated from the Chinese liverwort Chiloscyphus polyanthus var. rivularis (Schrad.) Nees. Their structures were determined by their spectroscopic data, single-crystal X-ray diffraction, and ECD calculations.

Biogenetically, the cyperane-type sesquiterpenoid is a kind of rearranged eudesmane-type sesquiterpenoid, ${ }^{\mathbf{1 6}}$ that is relatively uncommon and has only been isolated from a handful of plants, such as Tritomaria quinquedentata,${ }^{\mathbf{1 3}}$ Achillea clypeolata,${ }^{\mathbf{1 6}}$ and Cyperus rotundu. ${ }^{24}$ Our study has enriched the chemical and biological diversity of this small group of natural sesquiterpenoids. Additionally, compound 2 is the first trans-cyperane-type 
sesquiterpenoid. The co-presence of $\mathbf{1}$ and $\mathbf{2}$ confirmed that cyperane-type sesquiterpenoids formed through the cleavage at C-4/C-5 and the linkage at C-3/C-5 on the basis of eudesmane skeleton.

\section{Conflicts of interest}

There are no conflicts exist.

\section{Acknowledgements}

This work was supported financially by the National Natural Science Foundation of China (No. 81630093 and 81703375), and Natural Science Foundation of Shandong Province, China (ZR2017BH068).

\section{References}

1 J. L. Gross, M. J. de Azevedo, S. P. Silveiro, L. H. Canani, M. L. Caramori and T. Zelmanovitz, Diabetes Care, 2005, 28, 164-176.

2 A. Y. Wu, N. L. F. Kong, C. Y. Pan, T. Y. Tai, V. T. Yeung, S. J. Yoo, A. Rouillon and M. R. Weir, Diabetologia, 2005, 48, 17-26.

3 R. Kikkawa, D. Koya and M. Haneda, Am. J. Kidney Dis., 2003, 41, 19-21.

4 R. M. Mason and N. A. Wahab, J. Am. Soc. Nephrol., 2003, 14, 1358-1373.

5 K. R. Tuttle, J. Am. Soc. Nephrol., 2005, 16, 1537-1538.

6 D. Fineberg, K. A. Jandeleit-Dahm and M. E. Cooper, Nat. Rev. Endocrinol., 2013, 9, 713-723.

7 J. B. He, J. Luo, L. Zhang, Y. M. Yan and Y. X. Cheng, Org. Lett., 2013, 15, 3602-3605.

8 Q. Q. Jia, J. C. Wang, J. Long, Y. Zhao, S. J. Chen, J. D. Zhai, L. B. Wei, Q. Zhang, Y. Chen and H. B. Long, Molecules, 2013, 18, 13061-13077.
9 T. F. Tzeng, S. S. Liou, C. J. Chang and I. M. Liu, Nutr. Metab., 2013, 10, 64.

10 Y. M. Yan, P. Fang, M. T. Yang, N. Li, Q. Lu and Y. X. Cheng, J. Ethnopharmacol., 2015, 165, 141.

11 Y. Asakawa, Pure Appl. Chem., 2007, 79, 557-580.

12 Y. Asakawa, A. Ludwiczuk and F. Nagashima, Phytochemistry, 2013, 91, 52-80.

13 S. Li, H. Shi, W. Chang, Y. Li, M. Zhang, Y. Qiao and H. Lou, Bioorg. Med. Chem., 2017, 25, 5764-5771.

14 J. Zhang, P. Fan, R. Zhu, R. Li, Z. Lin, B. Sun, C. Zhang, J. Zhou and H. Lou, J. Nat. Prod., 2014, 77, 1031-1036.

15 J. Z. Zhang, Y. N. Qiao, L. Li, Y. J. Wang, Y. Li, X. Fei, J. C. Zhou, X. Wang, P. H. Fan and H. X. Lou, Planta Med., 2016, 82, 1128-1133.

16 M. N. Todorova and E. T. Tsankova, Phytochemistry, 1999, 52, 1515-1518.

17 A. Baykal, S. Chakraborty, A. Dodoo and F. Jordan, Bioorg. Chem., 2006, 34, 380-393.

18 B. Ma, Z. Q. Lu, H. F. Guo and H. X. Lou, Helv. Chim. Acta, 2007, 90, 52-57.

19 J. P. Kutney and A. K. Singh, Can. J. Chem., 1982, 13, 18421846.

20 H. Hikino, Y. Hikino and T. Takemoto, Chem. Pharm. Bull., 1965, 13, 1417-1421.

21 S. Li, H. Niu, Y. Qiao, R. Zhu, Y. Sun, Z. Ren, H. Yuan, Y. Gao, Y. Li, W. Chen, J. Zhou and H. Lou, Bioorg. Med. Chem., 2018, 26, 2392-2400.

22 O. V. Dolomanov, L. J. Bourhis, R. J. Gildea, J. A. K. Howard and H. Puschmann, J. Appl. Crystallogr., 2009, 42, 339-341.

23 G. M. Sheldrick, Acta Crystallogr., 2008, 64, 112-122.

24 H. Hikino, K. Aota, Y. Maebayashi and T. Takemoto, Chem. Pharm. Bull., 1967, 15, 1349. 